\title{
Fast 3: a phase III randomized double-blind, placebo-controlled multicenter study of Icatibant for subcutaneous injection in patients with acute Attacks of Hereditary Angioedema (HAE)
}

\author{
B Ritchie
}

From Canadian Society of Allergy and Clinical Immunology Annual Scientific Meeting 2009

Halifax, Canada. 22-25 October 2009

\section{Background}

Herditary Angioedema (HAE) is a rare disorder $(1: 10,000-1: 50,000)$ characterized by episodic, localized edema of skin or mucosa of airway, genitourinary tract or gastrointestinal tract. It is due to inherited deficiency of the serpin known as $\mathrm{C} 1$ Inhibitor leading to unopposed kallikrein, producing excess bradykinin which binds to G-protein coupled receptors known as B1 and $\mathrm{B} 2$ receptors. Icatabant, a ten amino acid peptide analogue of bradykinin is an effective blocker of the B2 receptor and has been shown to provide rapid and complete relief of symptoms compared to Tranexamic acid (Fast1) or placebo (Fast-2). Rapid relief of laryngeal edema was confirmed in the open label arm. A new trial (Fast3) has begun. Primary Objective are to compare icatibant vs placebo on the time to symptom relief using a 3 symptom Visual Analog Scale (VAS) score during moderate to very severe acute cutaneous and/or abdominal attacks in patients with type I or type II hereditary angioedema (HAE). Secondary Objectives are to compare the global outcome following treatment with icatibant vs placebo using patient-reported (single symptom and 8 symptom composite score) and physician-reported outcome measures at 4 and 8 hours; to compare the time to almost complete symptom relief following treatment with icatibant vs placebo during moderate to very severe acute cutaneous and/or abdominal attacks; to assess safety and tolerability of icatibant vs placebo; and to assess the efficacy and safety of open-label icatibant treatment in patients experiencing laryngeal edema

Correspondence: bruce.ritchie@ualberta.ca

4-71 MSB, University of Alberta, Edmonton, AB, Canada T6G 2 B7 attacks. 88 patients, aged 18 or older, with an attack of at least moderate severity os skin, abdomen or larynx/ pharynx will be randomized to double-blind treatment with either $30 \mathrm{mg}$ of Icatabant SC or placebo.

Published: 12 May 2010

\section{doi:10.1186/1710-1492-6-S1-P27}

Cite this article as: Ritchie: Fast 3: a phase III randomized double-blind, placebo-controlled multicenter study of Icatibant for subcutaneous injection in patients with acute Attacks of Hereditary Angioedema (HAE). Allergy, Asthma \& Clinical Immunology 2010 6(Suppl 1):P27.

Submit your next manuscript to BioMed Central and take full advantage of:

- Convenient online submission

- Thorough peer review

- No space constraints or color figure charges

- Immediate publication on acceptance

- Inclusion in PubMed, CAS, Scopus and Google Scholar

- Research which is freely available for redistribution 